\title{
Predictors of burnout among physicians and advanced-practice clinicians in central New York
}

\author{
Anthony C. Waddimba ${ }^{* 1,2}$, Melinda A. Nieves ${ }^{1}$, Melissa Scribani ${ }^{1}$, Nicole Krupa ${ }^{1}$, Paul Jenkins ${ }^{1}$, John J. May ${ }^{1,3}$ \\ ${ }^{1}$ Research Institute, Bassett Healthcare Network/Bassett Medical Center, Cooperstown, NY, United States \\ ${ }^{2}$ Department of Pediatrics, Columbia University, College of Physicians and Surgeons, NY, United States \\ ${ }^{3}$ Department of Epidemiology, Columbia University, Mailman School of Public Health, NY, United States
}

Received: July 1, 2015

DOI: $10.5430 /$ jha.v4n6p21
Accepted: August 2, 2015

Online Published: August 10, 2015

\begin{abstract}
Background: Provider wellbeing is a barometer of the strength of healthcare systems/organizations. Burnout prevalence among physicians exceeds that among other adult workers in the United States. Rural-based practitioners might be at greater risk. Objective: We investigated predictors of burnout among group-employed providers within an integrated healthcare network. Methods: In a prospective observational study of physicians/advanced-practice clinicians serving an 8-county region of central New York, we linked administrative practice-setting data with responses to a questionnaire-survey comprising validated measures of burnout, resilience, work meaningfulness, satisfaction, risk aversion, and uncertainty/ambiguity tolerance. We included providers on the official payroll, excepting advisory board and/or research team members plus those who retired, resigned or were fired. $308(65.1 \%)$ of 473 eligible clinicians completed the survey. 59.1\% of these were physicians/doctoral-level practitioners; 40.9\% advanced-practice clinicians. We assessed burnout using a validated 5-level single-item measure formatted as a binary outcome of "burned out/burning out" (levels 3-5) versus not. We derived a parsimonious generalized linear mixed-effects regression of this outcome on provider demographics, work-related needs, risk aversion, satisfaction, and unit characteristics.

Results: Perceived workload, relatedness needs, practice satisfaction $\geq 75 \%$ of the time, dissatisfaction $\geq 50 \%$, resilience, and practicing on a small unit were the significant, independent predictors.

Conclusions: Heavy workloads, unmet relational needs, frequent dissatisfaction, low resilience, and serving on a small unit were most significantly associated with being "burned out/burning out". Feeling satisfied most of the time and high resilience were protective. Profession, specialty, autonomy, and support staffing were not statistically significant.
\end{abstract}

Key Words: Occupational burnout, Professional satisfaction, Stress resilience, Physicians, Physician assistants, Nurse practitioners, Quality of work life

\section{INTRODUCTION}

Increasing attention is being paid to provider well-being as an indicator of the quality of health systems and practice organizations. ${ }^{[1-4]}$ The escalating responsibilities and demands placed on practitioners in the health reform era have contributed to increased professional dissatisfaction, demoralization, and burnout. ${ }^{[5]}$ Prevalence rates for burnout, depression, suicidal ideation, and suicide among physicians exceed those of other adult workers in the United States (U.S.). ${ }^{[6-8]}$ Roughly $45.8 \%$ of physicians nationwide experience symptoms of burnout. ${ }^{[6]}$ Data for non-physician clinicians are scarce, but burnout is reported to be more States.

*Correspondence: Anthony C. Waddimba; Email: anthony.waddimba@bassett.org; Address: 1 Atwell Road, Cooperstown, NY 13326, United 
prevalent among physician assistants ${ }^{[9]}$ and less among nurse practitioners. ${ }^{[10]}$

Practitioners serving in non-metropolitan areas are more prone to burnout than counterparts in urban areas, due to job stresses/strains that are unique to or more pronounced in remote, underserved settings. ${ }^{[11]}$ Such challenges include lower pay, resource scarcity, heavier workloads, geographic/organizational isolation, and higher proportions of patients with multiple morbidities. ${ }^{[12]}$ Early identification of distressed clinicians in such settings is more exigent, so that timely interventions are implemented to limit hardship ${ }^{[13]}$ and/or build resilience. ${ }^{[14]}$ Reducing threats to rural provider well-being could improve workforce retention and, ultimately, healthcare access among non-metropolitan populations. ${ }^{[15]}$ Many studies that shaped policy or practice regarding rural provider well-being were conducted long ago. ${ }^{[16,17]}$ Data on the well-being of rural practitioners in this era of health system reform and organizational consolidation are still fragmented. ${ }^{[15,18]}$

We investigated predictors of high risk for burnout, as measured by a validated screening instrument, among physician and non-physician practitioners employed by a group-model healthcare network serving an eight-county area of rural, upstate New York. Studies often separately assess risk factors for physicians, ${ }^{[19]}$ physician assistants, ${ }^{[9]}$ and advancedpractice nurses. ${ }^{[20]}$ Yet rural clinicians from these professions typically serve together on the same team. ${ }^{[21]}$ We examined burnout among physicians, physician assistants, nurse practitioners, certified nurse midwives, nurse anesthetists, and pharmacists providing primary or specialist/subspecialist healthcare. Our conceptual model incorporated newer measures of affective well-being that are currently gaining traction in health workforce research.

\section{Methods}

\subsection{Study design}

The current study reports cross-sectional observational data from the Practitioner Resilience, Adaptability and Wellbeing Study (PRAWS), a longitudinal research project investigating a community of rural clinicians.

\subsection{Study setting}

An integrated healthcare delivery system that serves an eightcounty region of central, upstate New York is the setting for the parent project. This network incorporates one academic medical center that is affiliated with Columbia University College of Physicians and Surgeons, six community hospitals, 31 outreach clinics, and 19 school-based health centers. Driving distances from outlying practices to the academic medical center are between 4.9 and 66.5 miles. Twenty-six percent of practice sites rank as Rural-Urban Commuting Area (RUCA) code 10, the highest rural status. The employed medical staff comprises about 500 physicians and mid-level non-physician practitioners serving a population that is geographically dispersed over an area of 5,600 square miles.

\subsection{Sample selection/Data collection}

From September 2013 to January 2014, we conducted a baseline survey on satisfaction with practice, stress resilience, and occupational burnout among the providers. The main inclusion criterion was full-time or part-time salaried membership with the medical professional staff on the institutional payroll. We excluded temporary staff on locum tenens that lacked official ties to the institution. We also excluded medical/surgical residents, medical students, and other trainees. Out of 493 prospective recruits, three staff members retired, and five resigned or were involuntarily terminated during the planning/promotion phase of the study. 12 providers served on the advisory board for the study or the research team and were excluded. We sent, via both electronic mail and inter-office packaging, a pre-piloted self-administered five-page questionnaire to all remaining 473 providers. Completing the instrument took about 15-20 minutes, on average. Its contents included items inquiring about demographics plus a series of validated, reliable scales/items assessing the variables under study. The survey was publicized for two months prior to rollout via e-mails to the providers' listserv and presentations by the study team or advisory board at numerous medical staff and departmental/division meetings. The roll-out followed the standard procedures described in the literature. ${ }^{[22,23]}$ We supplemented survey data with aggregate administrative data provided by the institution about the constituent clinical units.

\subsection{Measures and variables}

\subsubsection{Main outcome}

Burnout, as measured by a non-proprietary single-item, five-level, self-report measure, was the dependent variable. Schmoldt, Freeborn and colleagues employed this measure in studying HMO physicians. ${ }^{[24,25]}$ The Physician Work Life Study (PWLS), ${ }^{[26]}$ Minimizing Error and Maximizing Outcome (MEMO) study, ${ }^{[27]}$ and Mississippi Workforce Study (MWS) ${ }^{[28]}$ also used the same measure. It has been validated against (the emotional exhaustion subscale of) the "gold standard" Maslach Burnout Inventory (MBI) among 307 Texas medical school graduates, ${ }^{[29]} 740$ Australian oncology care providers, ${ }^{[30]} 5,404$ primary care providers/staff at Veterans Affairs hospitals, ${ }^{[31]}$ and our study sample. ${ }^{[32]}$ The item poses the question: "Overall, how would you rate your level of burnout?" Each respondent self-reports as being at one of 
five levels: 1 = "I enjoy my work, I have no symptoms of burnout"; 2 = "Occasionally I am under stress, and I don't always have as much energy as I once did, but I don't feel burned out"; 3 = "I am definitely burning out and have one or more symptoms of burnout"; 4 = "The symptoms of burnout that I am experiencing will not go away"; and 5 = "I feel completely burned out and often wonder if I can go on. I am at the point where I may need some changes or may need to seek some sort of help". As in the previous studies cited above, we dichotomized the responses into a binary outcome of "burning out"/“burned out" (level $\geq 3$ ) versus "not burned out" (level $\leq 2)$.

\subsubsection{Covariates}

Independent variables included provider demographics (gender, age, marriage, clinical experience, organizational tenure, full-time status, profession, primary versus non-primary specialties), psychosocial profile (intrinsic work-related needs, meaningfulness of patient care, risk aversion, tolerance of uncertainty/ambiguity, stress/adversity resilience), perceived workload, job satisfaction, and unit characteristics (location, number of providers, nursing and support staff levels). To assess global job satisfaction, we adapted the affect frequency item in the Fordyce Emotions Questionnaire ${ }^{[33]}$ into a question asking respondents to estimate the percent of time that they were satisfied, dissatisfied, and neither satisfied nor dissatisfied ${ }^{[34]}$ with practice. Being a one-dimensional construct, global job satisfaction is reliably captured by a single item. ${ }^{[35]}$ We assessed work-related needs by the autonomy and relatedness subscales of the Basic Psychological Needs at Work Scale, ${ }^{[36]}$ work meaningfulness by the Personal Meaning in Patient Care Scale, ${ }^{[37]}$ stress resilience by the Brief Resilience Scale, ${ }^{[38]}$ risk aversion by two items from the Risk Taking Scale ${ }^{[39]}$ of the Jackson Personality Inventory, ${ }^{[40]}$ and tolerance of uncertainty/ambiguity by two items from the Physicians' Reactions to Uncertainty in Patient Care Scale. ${ }^{[41]}$ These are valid, reliable scales that are reported in the cited literature but a review of whose published psychometrics is outside the scope of this paper. We assessed perceived workload via five items inquiring about patient load, instances of leaving work undone, having to take work home, doing more than one's fair share of work, and neglecting personal health due to work. Each item had a four-point Likert-style response format ranging from 1 ("Never [0\% of the time]") to 4 ("Frequently [> $75 \%$ of the time]"). We summed up these items into a composite "perceived workload" scale, which showed high reliability (Item-scale Spearman correlations from 0.5954 to 0.7760 , $[p<.0001]$; ordinal coefficient alpha $=0.8096)$ and validity
(Goodness of Fit Index $=0.9741$; Comparative Fit Index = 0.9586; Normed Fit Index = 0.9459; Tucker-Lewis Index = 0.9172; Standardized Root Mean Square Residual = 0.0378).

\subsubsection{Statistical analysis}

We tested associations between covariates and the dichotomized outcome using the Chi-square test of proportions, Fisher's exact test, or Wilcoxon rank sum test as appropriate. We then derived generalized linear mixed regressions testing the association between the dependent variable and each covariate as a fixed effect, with clustering by service unit included as a random effect. Covariates with a significant univariate association were then combined into a predictive multivariable generalized linear mixed model that also incorporated the clustering random effect. Using a stepwise procedure, we synthesized the most parsimonious model comprising only covariates that retained significance independent of each other after accounting for clustering. We also tested for multicollinearity and assessed plausible interactions. Analyses were performed using Statistical Analysis Software (SAS) version 9.3 (SAS Inc., Cary, NC) with generalized linear mixed-effects models implemented via PROC GLIMMIX.

\section{RESULTS}

Out of 473 recipients, $308(65.1 \%)$ completed the survey. Respondents were $53.9 \%$ male, $80.5 \%$ married, $81.9 \%$ fulltime employees, $59.1 \%$ with doctoral degrees and $40.9 \%$ advanced-practice clinicians. Their mean (95\% confidence interval $[\mathrm{CI}])$ age and organizational tenure were 49.2 (47.9, $50.6)$ and $10.3(9.3,11.3)$ years respectively. Of the 305 respondents with complete data on the outcome, 100 (32.79\%) were either burned out or burning out (levels 3-5 on the single-item measure), while $205(67.21 \%)$ were not burned out (levels 1-2).

Figure 1 shows the distribution of the self-reported levels of burnout by provider attributes. Table 1 contrasts the respondents who were burning out or burned out with the rest. Table 2 outlines the univariate associations between each predictor variable and the outcome.

As illustrated in Table 2, each of these covariates had a significant univariate association with the outcome, after accounting for clustering within clinical units: being married, serving on a clinical unit with five or fewer providers, perceived workload, needs for autonomy, needs for relatedness with others, meaningfulness of patient-care practice, intolerance of uncertainty/ambiguity, frequency of being satisfied and/or dissatisfied with practice, and stress resilience. 


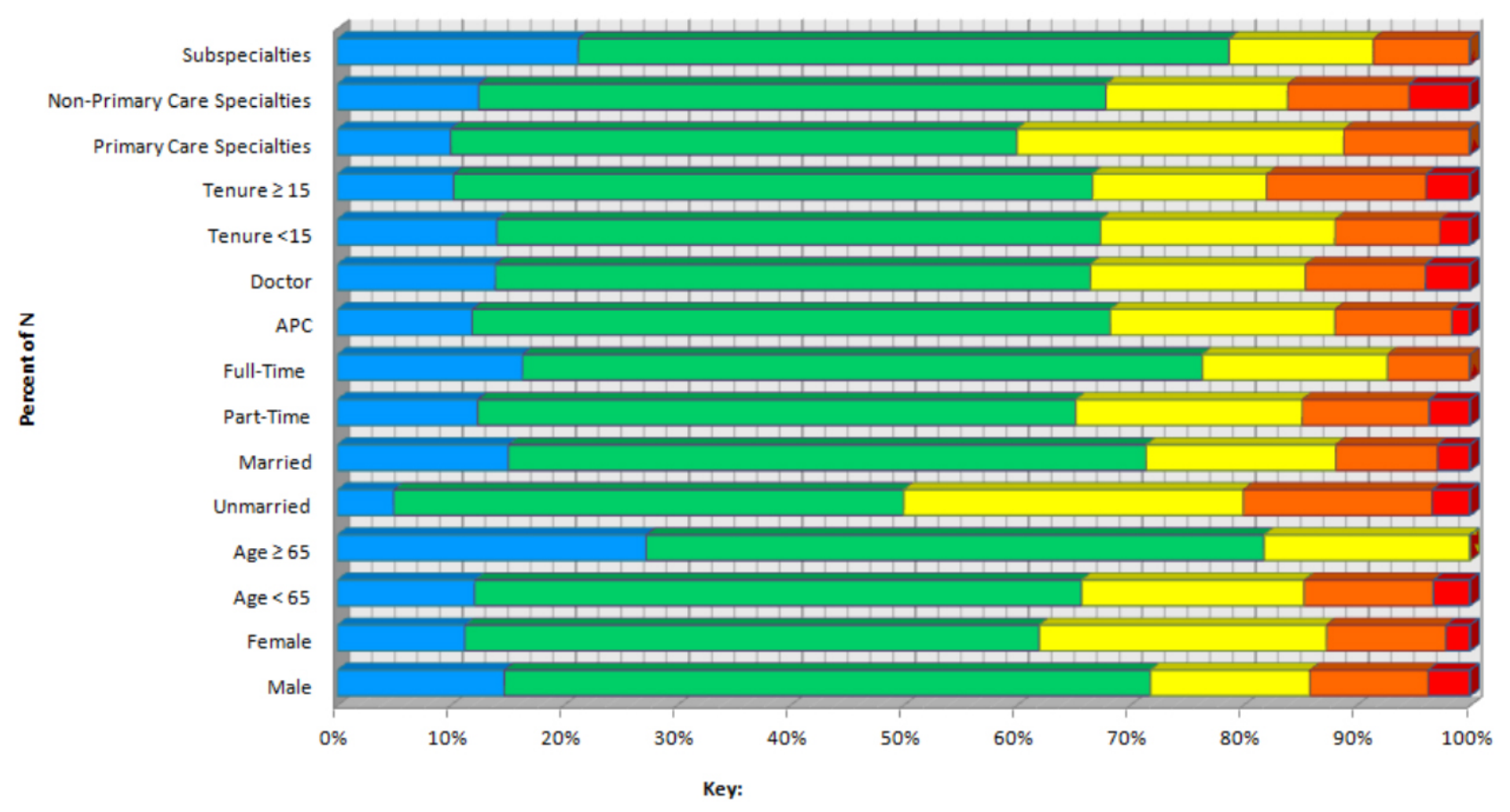

$\square$ 1: I enjoy my work $\square$ 2: Occasionally I am under stress $\square 3:$ I am definitely burning out $\square 4$ : Have symptoms of burnout $\square 5:$ I feel completely burned out

Figure 1. Distribution of responses on the single-item burnout measure

Table 1. Characteristics of the practitioners and their clinical units or practices

\begin{tabular}{|c|c|c|c|c|}
\hline & Variable & $\begin{array}{l}\text { Overall Study } \\
\text { Sample }\end{array}$ & $\begin{array}{l}\text { At High Risk for } \\
\text { Burnout }(\mathrm{n}=100)\end{array}$ & $\begin{array}{l}\text { Not at High Risk for } \\
\text { Burnout }(n=205)\end{array}$ \\
\hline \multirow{10}{*}{$\begin{array}{l}\text { Provider } \\
\text { Demographics }\end{array}$} & Male Gender (\%) & 53.9 & 46.0 & 57.1 \\
\hline & Married (\%) & 80.5 & $70.0^{*}$ & $85.4^{*}$ \\
\hline & Age, years (mean, STD) & $49.2(11.8)$ & $49.1(11.2)$ & $49.1(12.0)$ \\
\hline & Aged $\geq 65$ years $(\%)$ & 7.5 & 4.0 & 8.9 \\
\hline & Organizational Tenure, years (mean, STD) & $10.3(9.0)$ & $10.5(8.3)$ & $10.1(9.3)$ \\
\hline & Organizational Tenure $\geq 20$ years $(\%)$ & 18.5 & 19.0 & 18.1 \\
\hline & Works full time (\%) & 81.8 & 87.0 & 79.5 \\
\hline & Advanced-Practice Clinician (\%) & 40.91 & 40.0 & 41.95 \\
\hline & Physician or other Doctor (\%) & 59.09 & 60.0 & 58.05 \\
\hline & Works in primary health care $(\%)$ & 32.1 & 39.0 & 28.3 \\
\hline \multirow{4}{*}{$\begin{array}{l}\text { Clinical Unit } \\
\text { Characteristics }\end{array}$} & No. of Providers on the Unit (median, $\mathrm{q} 1-\mathrm{q} 3$ ) & $8(4,16)$ & $7(4,16)$ & $11(5,21)$ \\
\hline & Small Clinical Unit $[\leq 5$ providers only] $(\%)$ & 30.7 & $39.8^{*}$ & $26.1^{*}$ \\
\hline & Total Support Staff F.T.E’s (median, q1-q3) & $5.1(2,9)$ & $5.2(2,9)$ & $4(2,7.6)$ \\
\hline & Support Staff F.T.E's per Provider (median, q1-q3) & $0.3(0.2,2.0)$ & $0.5(0.2,2.2)$ & $0.3(0.2,1.6)$ \\
\hline \multirow{11}{*}{$\begin{array}{l}\text { Providers' } \\
\text { Psychosocial } \\
\text { Disposition }\end{array}$} & Perceived Workload score (median, q1-q3) & $12(10,14)$ & $14(12,16)^{*}$ & $11(9,13)^{*}$ \\
\hline & Autonomy needs (median, q1-q3) & $5.3(4.8,5.8)$ & $4.8(4.0,5.5)^{*}$ & $5.5(5.0,5.8)^{*}$ \\
\hline & Relatedness needs (median, q1-q3) & $5.0(4.3,5.3)$ & $4.3(3.5,5.0)^{*}$ & $5.0(4.5,5.5)^{*}$ \\
\hline & Perceived Meaning in Patient Care (median, $\mathrm{q} 1-\mathrm{q} 3$ ) & $3.3(2.8,3.7)$ & $3.2(2.7,3.7)$ & $3.3(3.0,3.8)$ \\
\hline & Risk Aversion (median, q1-q3) & $5(4,6)$ & $5(4,6)$ & $5(4,6)$ \\
\hline & Intolerance of Uncertainty/Ambiguity (median, q1-q3) & $5(4,6)$ & $6(4,6)$ & $5(4,6)$ \\
\hline & Percent of Time Satisfied (median, q1-q3) & $60(30,80)$ & $30(20,50)^{*}$ & $75(50,90)^{*}$ \\
\hline & Satisfied $\geq 75$ of the time $(\%)$ & 41.3 & $10.2^{*}$ & $56.5^{*}$ \\
\hline & Percent of Time Dissatisfied (median, q1-q3) & $20(10,30)$ & $40(25,55)^{*}$ & $10(5,24)^{*}$ \\
\hline & Dissatisfied $\geq 50$ of the time (\%) & 18.9 & $46.4^{*}$ & $4.4^{*}$ \\
\hline & Brief Resilience Scale score (median, q1-q3) & $3.2(2.7,3.7)$ & $3.2(2.7,3.8)^{*}$ & $4.0(3.3,4.3)^{*}$ \\
\hline
\end{tabular}


Table 2. Univariate generalized linear mixed regressions of individual predictors of high risk for occupational burnout

\begin{tabular}{|c|c|c|c|c|}
\hline & Variable & $\begin{array}{l}\text { Parameter Coefficient } \\
\text { (Standard Error) }\end{array}$ & $F$ test ( $p$-value) & $\begin{array}{l}\text { Unadjusted Odds } \\
\text { Ratio (95\% CI) }\end{array}$ \\
\hline \multirow{10}{*}{$\begin{array}{l}\text { Provider } \\
\text { Demographics }\end{array}$} & Male Gender & $-0.4005(0.2599)$ & $2.37(.1317)$ & $0.67(0.40-1.13)$ \\
\hline & Married & $-0.9839(0.3161)$ & $9.69(.0040)^{*}$ & $0.37(0.20-0.71)^{*}$ \\
\hline & Age, years & $-0.00214(0.01129)$ & $0.04(.8499)$ & $1.00(0.98-1.02)$ \\
\hline & Aged $<65$ years & $1.0042(0.6087)$ & $2.72(.1249)$ & $2.73(0.73-10.28)$ \\
\hline & Organizational Tenure, years & $0.004156(0.01444)$ & $0.08(.7737)$ & $1.00(0.98-1.03)$ \\
\hline & Organizational Tenure $\geq 20$ years & $0.00922(0.3334)$ & $0.00(.9782)$ & $1.01(0.51-2.01)$ \\
\hline & Works full time & $0.6645(0.3694)$ & $3.24(.0833)$ & $1.94(0.91-4.15)$ \\
\hline & Physician or other Doctor & $0.0403(0.2723)$ & $0.02(.8834)$ & $1.04(0.60-1.82)$ \\
\hline & Advanced-Practice Clinician & $-0.0403(0.2723)$ & $0.02(.8834)$ & $0.96(0.55-1.68)$ \\
\hline & Works in primary health care & $0.4735(0.3020)$ & $2.46(.1609)$ & $1.61(0.79-3.28)$ \\
\hline \multirow{4}{*}{$\begin{array}{l}\text { Clinical Unit } \\
\text { Characteristics }\end{array}$} & No. of Providers on the Unit & $-0.02410(0.01485)$ & $2.63(.1087)$ & $0.98(0.95-1.00)$ \\
\hline & Small Clinical Unit ( $\leq 5$ providers only) & $0.6109(0.3069)$ & $3.96(.0500)^{*}$ & $1.84(1.00-3.39)^{*}$ \\
\hline & Total Support Staff F.T.E’s & $0.007426(0.01850)$ & $0.16(.6893)$ & $1.01(0.97-1.05)$ \\
\hline & Support Staff F.T.E's per Provider & $0.08059(0.06767)$ & $1.42(.2373)$ & $1.08(0.95-1.24)$ \\
\hline \multirow{11}{*}{$\begin{array}{l}\text { Provider's } \\
\text { Psychosocial } \\
\text { Disposition }\end{array}$} & Perceived Workload score & $0.3234(0.04879)$ & $43.94(<.0001)^{*}$ & $1.38(1.26-1.52)^{*}$ \\
\hline & Autonomy needs & $-0.6382(0.1367)$ & $21.79(<.0001)^{*}$ & $0.53(0.40-0.69)^{*}$ \\
\hline & Relatedness needs & $-0.8395(0.1498)$ & $31.42(<.0001)^{*}$ & $0.43(0.32-0.58)^{*}$ \\
\hline & Perceived Meaning in Patient Care & $-0.4534(0.2159)$ & $4.41(.0369)^{*}$ & $0.64(0.42-0.97)^{*}$ \\
\hline & Risk Aversion & $0.1586(0.09623)$ & $2.72(.1008)$ & $1.17(0.97-1.42)$ \\
\hline & Intolerance of Uncertainty & $0.2896(0.09648)$ & $9.01(.0030)^{*}$ & $1.34(1.11-1.62)^{*}$ \\
\hline & Percent of Time Satisfied & $-0.06066(0.00776)$ & $61.10(<.0001)^{*}$ & $0.94(0.93-0.96)^{*}$ \\
\hline & Satisfied $\geq 75$ of the time & $-2.5174(0.3870)$ & $42.31(<.0001)^{*}$ & $0.08(0.04-0.18)^{*}$ \\
\hline & Percent of Time Dissatisfied & $0.08706(0.01067)$ & $66.64(<.0001)^{*}$ & $1.09(1.07-1.11)^{*}$ \\
\hline & Dissatisfied $\geq 50$ of the time & $2.9297(0.4223)$ & $48.12(<.0001)^{*}$ & $18.72(7.85-44.68)^{*}$ \\
\hline & Brief Resilience Scale score & $-1.0640(0.1947)$ & $29.85(<.0001)^{*}$ & $0.35(0.24-0.51)^{*}$ \\
\hline
\end{tabular}

${ }^{*} p<.05$

Table 3. Parsimonious linear mixed regression model of predictors of high risk for occupational burnout

\begin{tabular}{llll}
\hline Independent Variable & $\begin{array}{l}\text { Parameter Coefficient } \\
\text { (Standard Error) }\end{array}$ & F test (p-value) & $\begin{array}{l}\text { Adjusted Odds Ratio } \\
\text { (95\% CI) }\end{array}$ \\
\hline Intercept & $0.9936(1.4828)$ & & $1.281(1.114-1.473)$ \\
Perceived Workload & $0.2474(0.07075)$ & $12.22(.0006)$ & $0.496(0.337-0.731)$ \\
Relatedness Needs & $-0.7010(0.1963)$ & $12.75(.0005)$ & $6.893(2.399-19.811)$ \\
Dissatisfied $\geq 50 \%$ of the time & $1.9306(0.5090)$ & $14.38(.0010)$ & $0.303(0.115-0.795)$ \\
Satisfied $\geq 75 \%$ of the time & $-1.1952(0.4740)$ & $6.36(.0169)$ & $0.587(0.348-0.990)$ \\
Brief Resilience Scale score & $-0.5328(0.2646)$ & $4.05(.0457)$ & $2.489(1.107-5.593)$ \\
Small Clinical Unit $(\leq 5$ providers only) & $0.9117(0.4059)$ & $5.05(.0279)$ & \\
\hline
\end{tabular}

Note. -2 Log Likelihood = 188.48; Akaike Information Criterion $($ AIC $)=202.48$; Bayesian Information Criterion $($ BIC $)=218.22 ;$ Pearson Chi-Square $=218.78$; Pearson Chi-Square/DF = 0.90; Area under the ROC curve (c-statistic) $=0.897$

Table 3 shows the results and the goodness of fit statistics of the predictive multivariable generalized linear mixed regression model. In the most parsimonious multivariable model that we synthesized, these factors retained significance independent of each other while accounting for clustering: perceived workload, relatedness needs, being satisfied $\geq 75 \%$ of the time, being dissatisfied $\geq 50 \%$ of the time, resilience, and serving on a unit with $\leq 5$ providers.

Published by Sciedu Press
Each unit increase in perceived workload was associated with a multiplicative increase in the independent odds of being burned out/burning out by 1.28 $(\mathrm{CI}=1.11,1.47)$. An increase of one in the relatedness score was, on average, associated with a reduction by 0.50 $(\mathrm{CI}=0.34,0.73)$ in the multiplicative odds of the outcome. Satisfaction with practice $\geq 75 \%$ of the time was independently associated with a reduction by 0.30 
$(\mathrm{CI}=0.12,0.80)$ in the multiplicative odds of burning out/being burned out, whereas being dissatisfied $\geq 50 \%$ was linked to a 6.89 -fold $(\mathrm{CI}=2.40,19.81)$ increase in odds. A single unit increase in the BRS score was associated with an average reduction of 0.59 $(\mathrm{CI}=0.35,0.99)$ in the outcome's multiplicative odds. A 2.49 -fold $(\mathrm{CI}=1.11,5.59)$ increase in burnout odds was independently associated with service on a unit comprising $\leq 5$ providers.

Figure 2 shows the receiver operating characteristic (ROC) curve for the parsimonious model. The area under the curve $(c=0.897)$ implies that the model correctly discriminates providers who are burning/burned out from the rest in almost $90 \%$ of cases.

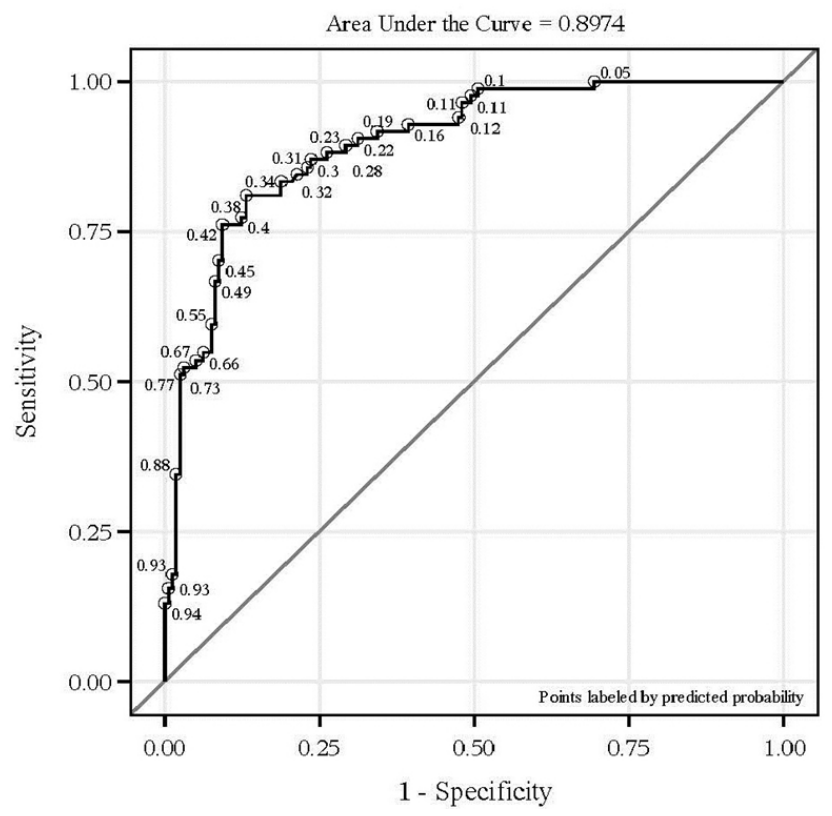

Figure 2. Receiver operating characteristic (ROC) plot

\section{Discussion}

We investigated predictors of being burned out or burning out among physicians and advanced-practice clinicians employed by an integrated healthcare network to serve a rural, underserved, population geographically dispersed over eight counties and 5,600 square miles in central New York State. In a parsimonious multivariable model, providers at greatest risk were those who reported carrying a heavy workload, had unmet relatedness needs, frequently felt dissatisfied with practice, manifested low stress resilience, and served on small clinical units. Protective factors were lighter workloads, fulfilled relational needs, more frequent satisfaction, high resilience, and practicing on bigger units.

The finding that high workload was a risk factor supports previous studies that linked high workload to increased job distress among physicians. ${ }^{[42]}$ Job control/autonomy and organizational support are thought to moderate the effect of high workload on affective distress. ${ }^{[43,44]}$ Greater professional control and maximum organizational support reduce distressing effects of heavy workload on healthcare providers. The effect of heavy workload on patient care is also moderated by the relational climate at work. ${ }^{[45]}$ Perceived workload is a more potent predictor of burnout than objective measures of workload, such as case load, because practitioners, like all human beings, are frequently motivated by perceptions rather than objective reality. ${ }^{[46]}$ Strategies such as allowing a healthy degree of control (especially over schedules) plus implementing team-based ${ }^{[47,48]}$ and collaborative care models ${ }^{[49]}$ can reduce perceptions of heavy workload.

The importance of gratifying practitioner needs for healthy relationships was highlighted by this study. Collegial support for practitioners by their peers and patients improves the working climate and boosts professional satisfaction. ${ }^{[50,51]}$ Healthy professional relationships help providers to cope with job stresses/strains ${ }^{[52]}$ and are associated with lower burnout. ${ }^{[53]}$ Supportive relationships with their professional colleagues are valued more than employee assistance programs instituted by management. ${ }^{[54]}$ The lower the amount of self-determination/autonomy that practitioners can exercise, the more they tend to lean on supportive relationships. ${ }^{[55]}$ Workplace relationships influence providers' attrition from practice. ${ }^{[53,56]}$ Among employed providers, social relationships influence the quality of work life more significantly than staff support, job control, income, or time pressure. ${ }^{[57]}$ Electronic medical records (EMRs) have diminished the time that providers spend in direct contact with patients. ${ }^{[58,59]}$ Since they derive much satisfaction from personal communication with patients, ${ }^{[60]}$ this isolating effect of the EMR has heightened professional discontent. ${ }^{[61,62]}$ The authors will, in a separate report, publish qualitative data highlighting the EMR as a stressor among respondents to the PRAWS baseline survey.

The day-to-day levels of either satisfaction or frustration with clinical practice are an important finding in this study. Most previous studies tended to assess satisfaction on an either/or satisfied/dissatisfied basis. Our conceptual approach, of examining satisfaction as an affective state that fluctuates, led us to focus on the proportion of time that a provider is dissatisfied and/or satisfied rather than simply on the presence or absence of satisfaction. Our intuition, in this study, is more in tune with the real world of clinical practice where the practitioner's experience might swing from joy to frustration from one moment to another. Most significant risk factors for burnout among providers probably act by influencing their day-to-day job satisfaction. Provider satisfac- 
tion is increasingly recognized an important indicator of the quality of healthcare processes, systems, and institutions/organizations. ${ }^{[1-3,63,64]}$

Resilience to stress/adversity was also highlighted as an important risk factor in this study. The positive psychology movement has revived interest in this construct. ${ }^{[65]}$ The downstream effects of numerous other risk factors (on the likelihood of burnout) are likely to be, at least partially, mediated and moderated by resilience. When dispositional resilience takes a toll from the day-to-day stresses and strains of the clinical workplace, the practitioner could adapt, grow and thrive from the experience (becoming more resilient) or they could suffer from vicarious trauma/compassion fatigue (becoming less resilient) and burn out. ${ }^{[66]}$ Resilience-building factors such as high-quality relationships, a healthy work climate, and a supportive organizational framework could aid psychological growth and vitality, preventing burnout. ${ }^{[67]}$ Personal qualities such as frequent activation of positive emotion could also be helpful in coping with stress. ${ }^{[68]}$ Compassion satisfaction (the pleasure from helping others), tolerating clinical uncertainty, and finding intrinsic personal meaning in patient care might play a similar role. ${ }^{[69]}$ Coaching medical professionals in enhanced stress management and resilience skills could therefore help to prevent burnout. ${ }^{[14,70,71]}$ Not just individuals, but entire practices and/or healthcare organizations can be re-engineered to improve resilience. ${ }^{[72]}$

Unlike the recent Medscape Physician Lifestyles Report, ${ }^{\text {[73] }}$ we detected no significant difference in burnout risk by gender. Also, unlike Keeton et al. ${ }^{\left[{ }^{[7]}\right.}$ we found no independent multivariate effect (despite a significant bivariate effect) for autonomy probably due to some confounding with relatedness. The more significant multivariate effect of relational needs when compared to autonomy contradicts the popular stereotype of providers, especially physicians, ${ }^{[53]}$ as "lone wolf" professionals. The respondents reported professional social interactions as being central to their well-being. The significant effect for marriage in bivariate models did not persist in multivariate models due to confounding with relatedness. Married providers perceived a greater fulfillment of their relational needs than unmarried colleagues. Practicing on a clinical unit with $\leq 5$ providers independently predicted burnout odds in this study, whereas other "staffing level" variables were not significant. Those serving on small units tended to have less peer support coupled with higher average workloads per provider.

\subsection{Limitations}

External validity of our findings could be limited by characteristics of the study setting and by the kind of selection biases often associated with surveys. We tested for sys-

Published by Sciedu Press tematic differences in attributes between respondents and non-responders. There were no significant differences on demographics except for organizational tenure (respondents had served a median of 7.8 years at the organization versus 4.8 for non-responders; $p<.0001)$. Since the proportion of burned out/burning out respondents in this study $(32.8 \%)$ resembles those reported by Hansen and Girgis $(32.0 \%)^{[30]}$ plus Dolan and colleagues $(38.5 \%),{ }^{[31]}$ our findings could generalize to different settings more than we had anticipated. Validation studies find the single-item self-report measure to be a better proxy for emotional exhaustion than for other aspects of burnout. ${ }^{[32]}$ Our findings should, therefore, be cautiously interpreted as more indicative of emotional exhaustion than depersonalization or low sense of achievement.

\subsection{Implications}

Our findings have strong and clear implications for practitioners, patients, practice managers, hospital and clinic administrators, and healthcare organization leaders. Provider satisfaction ought to be as routinely monitored as patient satisfaction, to enable early identification of and psychosocial support for those at risk of occupational burnout, which endangers patient care quality and continuity, and increases turnover among the clinician workforce. Healthcare organization managers must build resilient workplaces in order to reduce practitioner/staff burnout in medical practice. Community-building measures to strengthen social networks could reduce loneliness among rural providers. Social and organizational isolation is especially challenging to rural-based practitioners since many health service outlets are located far from the flagship medical center and are widely dispersed geographically from one another. Concerns over fairness or equity in division of clinical labor might be addressed via team-based models of care delivery. Greater provider awareness of risk factors in clinical settings can help to break the stigma or myth surrounding burnout, paving the way for advocacy plus effectiveness trials of prevention programs. Providers need coaching in stress resilience skills and workhome balancing strategies.

\section{Conclusion}

Among physicians and advanced practice clinicians in a rural, underserved area of central New York, the most significant risk factors for burning out or being burned out were: perceptions of heavy workload, unfulfilled needs for relatedness, dissatisfaction $\geq 50 \%$ of the time, low resilience, and service on a small clinical unit. Being satisfied the majority of the time and being highly resilient were protective factors. Once these key factors were accounted for, the effects of clinical specialty, scope of practice, autonomy perceptions, or levels of support staffing were relatively minimal. These findings 
show that the key risk factors for burnout are mutable and specific efforts targeting these predictors might effectively reduce burnout among practitioners in rural, underserved clinical settings.

\section{ACKNOWLEDGEMENTS}

The authors sincerely thank all the physicians, dentists, pharmacists and advanced-practice clinicians who generously responded to the PRAWS baseline survey. We are grateful to the Advisory Board for their guidance. The President of the Bassett Medical Group, Reginald Knight, MD, and his Executive helped in championing and publicizing the survey. Shannon Crisman coordinated the earliest phases of the PRAWS project. Cosby Gibson acted for some time as a liaison between the Research Team and the Advisory Board. An earlier draft of this manuscript benefited from comments made by Douglas Delong, MD, of the Division of General Internal Medicine at Bassett Medical Center. The editors and peer reviewers of the Journal of Hospital Admin- istration deserve our thanks for their insightful suggestions. We further acknowledge Laura Dixon, MLS, Manager of the McKenzie Medical Library at Bassett Medical Center, and her staff for acting on behalf of the research team to secure the permissions and procure the manuals for the proprietary scales that are utilized in the PRAWS project.

\section{FUNDING}

No extramural funding supported this study.

\section{CONFlicts of InTEREST Disclosure}

The authors report no financial conflict(s) of interest.

\section{DiSCLAIMER}

The findings that are reported in this manuscript are solely those of the authors and do not represent the official or unofficial views of any of the institutions that the authors are either individually or jointly affiliated to.

\section{REFERENCES}

[1] Grembowski D, Ulrich CM, Paschane D, et al. Managed Care and Primary Physician Satisfaction. Journal of the American Board of Family Medicine. 2003; 16(5): 383-393. http://dx.doi.org/10. 3122/jabfm.16.5.383

[2] Wallace JE, Lemaire JB, Ghali WA. Physician Wellness: A Missing Quality Indicator. Lancet. 2009; 374(9702): 1714-1721. http: //dx.doi.org/10.1016/S0140-6736(09)61424-0

[3] Bodenheimer T, Sinsky C. From Triple to Quadruple Aim: Care of the Patient Requires Care of the Provider. Annals of Family Medicine. 2014; 12(6): 573-576. PMid: 25384822. http://dx.doi.org/10. 1370/afm. 1713

[4] Montgomery A, Panagopoulou E, Kehoe I, et al. Connecting Organisational Culture and Quality of Care in the Hospital: Is Job Burnout the Missing Link? Journal of Health Organization and Management. 2011; 25(1): 108-123. PMid: 21542465. http://dx.doi.org/10. 1108/14777261111116851

[5] Dyrbye LN, Shanafelt TD. Physician Burnout: A Potential Threat to Successful Health Care Reform. Journal of the American Medical Association. 2011; 305(19): 2009-2010. PMid: 21586718. http://dx.doi.org/10.1001/jama. 2011.652

[6] Shanafelt TD, Boone S, Tan L, et al. Burnout and Satisfaction With Work-Life Balance Among U.S. Physicians Relative to the General U.S. Population. Archives of Internal Medicine. 2012; 172(18): $1377-$ 1385. PMid: 22911330. http://dx.doi.org/10.1001/archint ernmed.2012.3199

[7] Gold KJ, Sen A, Schwenk TL. Details on Suicide among U.S. Physicians: Data from the National Violent Death Reporting System. General Hospital Psychiatry. 2013; 35(1): 45-49. PMid: 23123101. http: //dx.doi.org/10.1016/j.genhosppsych.2012.08.005

[8] Dyrbye LN, Satele D, Sloan J, et al. Ability of the Physician Wellbeing Index to Identify Residents in Distress. Journal of Graduate Medical Education. 2014; 6(1): 78-84. PMid: 24701315. http://dx.doi.org/10.4300/JGME-D-13-00117.1
[9] Bell RB, Davison M, Sefcik D. A First Survey. Measuring Burnout in Emergency Medicine Physician Assistants. Journal of the American Academy of Physician Assistants. 2002; 15(3): 40-2, 45-8, 51-2 passim. PMid: 11949543.

[10] Schiestel C. Job Satisfaction Among Arizona Adult Nurse Practitioners. Journal of the American Academy of Nurse Practitioners. 2007; 19(1): 30-34. PMid: 17214865. http://dx.doi.org/10.1111/j $.1745-7599.2006 .00187 . \mathrm{x}$

[11] Stevenson AD, Phillips CB, Anderson KJ. Resilience among Doctors Who Work in Challenging Areas: A Qualitative Study. British Journal of General Practice. 2011; 61(588): e404-e410. PMid: 21722448. http://dx.doi.org/10.3399/bjgp11X583182

[12] Morley CP. Supporting Physicians Who Work in Challenging Contexts: A Role for the Academic Health Center. Journal of the American Board of Family Medicine. 2012; 25(6): 756-758. PMid: 23136311. http://dx.doi.org/10.3122/jabfm. 2012 . 06.120250

[13] Ensz GR, Kruger K. A Solution for Rural Physician Burnout: The Creation of the PEERist. Journal of Medical Practice Management. 2010; 26(1): 53-56. PMid: 20839515.

[14] Longenecker R, Zink T, Florence J. Teaching and Learning Resilience: Building Adaptive Capacity for Rural Practice. A Report and Subsequent Analysis of a Workshop Conducted at the Rural Medical Educators Conference, Savannah, Georgia, May 18, 2010. Journal of Rural Health. 2012; 28(2): 122-127. PMid: 22458312. http://dx.doi.org/10.1111/j.1748-0361.2011.00376.x

[15] Haggerty TS, Fields SA, Selby-Nelson EM, et al. Physician Wellness in Rural America: A Review. International Journal of Psychiatry in Medicine. 2013; 46(3): 303-313. PMid: 24741836 http: //dx.doi.org/10.2190/PM.46.3.e

[16] Muus KJ, Geller JM, Williams JD, et al. Job Satisfaction Among Rural Physician Assistants. Journal of Rural Health. 1998; 14(2): 100-108. PMid: 9714998. http://dx.doi.org/10.1111/j.174 8-0361.1998.tb00611.x 
[17] Pathman DE, Williams ES, Konrad TR. Rural Physician Satisfaction: Its Sources and Relationship to Retention. Journal of Rural Health. 1996; 12(5): 366-377. PMid: 10166133. http://dx.doi.org/10. 1111/j.1748-0361.1996.tb00804.x

[18] Henry LR, Hooker RS, Yates KL. The Role of Physician Assistants in Rural Health Care: A Systematic Review of the Literature. Journal of Rural Health. 2011; 27(2): 220-229. PMid: 21457316. http://dx.doi.org/10.1111/j.1748-0361.2010.00325.x

[19] Dyrbye LN, Varkey P, Boone SL, et al. Physician Satisfaction and Burnout at Different Career Stages. Mayo Clinic Proceedings. 2013; 88(12): 1358-1367. PMid: 24290109. http://dx.doi.org/10. 1016/j.mayocp. 2013.07.016

[20] Browning L, Ryan CS, Thomas S, et al. Nursing Specialty and Burnout. Psychology Health and Medicine. 2007; 12(2): 248-254. http://dx.doi.org/10.1080/13548500600568290

[21] Peterson LE, Blackburn B, Petterson S, et al. Which Family Physicians Work Routinely with Nurse Practitioners, Physician Assistants or Certified Nurse Midwives. Journal of Rural Health. 2014; 30(3): 227-234. PMid: 24330195. http://dx.doi.org/10.1111/jrh .12053

[22] Thorpe C, Ryan B, McLean S, et al. How to Obtain Excellent Response Rates When Surveying Physicians. Family Practice. 2009; 26(1): 65-68. PMid: 19074758. http://dx.doi.org/10.1093/f ampra/cmn097

[23] Dillman DA, Smyth JD, Christian LM. Internet, Phone, Mail, and Mixed-Mode Surveys: The Tailored Design Method, $4^{t h}$ Edition. Hoboken, NJ: John Wiley and Sons; 2014.

[24] Schmoldt RA, Freeborn DK, Klevit HD. Physician Burnout: Recommendations for HMO Managers. HMO Practice / HMO Group. 1994; $8(2): 58-63$

[25] Freeborn DK. Satisfaction, Commitment, and Psychological Wellbeing Among HMO Physicians. Western Journal of Medicine. 2001; 174(1): 13-18. PMid: 11154654. http://dx.doi.org/10.1136 /ewjm.174.1.13

[26] McMurray JE, Linzer M, Konrad TR, et al. The Work Lives of Women Physicians: Results from the Physician Work Life Study. The SGIM Career Satisfaction Study Group. Journal of General Internal Medicine. 2000; 15(6): 372-380. PMid: 10886471.

[27] Williams ES, Manwell LB, Konrad TR, et al. The Relationship of Organizational Culture, Stress, Satisfaction, and Burnout with Physician-reported Error and Sub-optimal Patient Care: Results from the MEMO Study. Health Care Management Review. 2007; 32(3): 203-212. PMid: 17666991. http://dx.doi.org/10.1097 /01. HMR. 0000281626.28363 .59

[28] Cossman JS, Street D. Mississippi Burnout. Part I: Personal Characteristics and Practice Context. Journal of the Mississippi State Medical Association. 2009; 50(9): 306-310. PMid: 20812443.

[29] Rohland BM, Kruse GR, Rohrer JE. Validation of a Single-Item Measure of Burnout Against the Maslach Burnout Inventory Among Physicians. Stress and Health. 2004; 20(2): 75-79. http://dx.doi .org/10.1002/smi. 1002

[30] Hansen V, Girgis A. Can a Single Question Effectively Screen for Burnout in Australian Cancer Care Workers? BMC Health Services Research. 2010; 10: 341. PMid: 21162747. http://dx.doi.org /10.1186/1472-6963-10-341

[31] Dolan ED, Mohr D, Lempa M, et al. Using a Single Item to Measure Burnout in Primary Care Staff: A Psychometric Evaluation. Journal of General Internal Medicine. 2015; 30(5): 582-587. PMid: 25451989. http://dx.doi.org/10.1007/s11606-014 $-3112-6$

[32] Waddimba AC, Scribani M, Nieves M, et al. Validation of SingleItem Screening Measures for Provider Burnout in a Rural Healthcare
Network. Evaluation and the Health Professions. 2015 [Epub ahead of print]. PMid: 25716107. http://dx.doi.org/10.1177/016 3278715573866

[33] Fordyce MW. A Review of Research on the Happiness Measures: A Sixty Second Index of Happiness and Mental Health. Social Indicators Research. 1988; 20(4): 355-381. http://dx.doi.org/10.10 $07 / \mathrm{BF} 00302333$

[34] Fields DL. Job Satisfaction, in Taking the Measure of Work: A Guide to Validated Scales for Organizational Research and Diagnosis. SAGE Publications, Inc: Thousand Oaks, CA; 2002. 11 p.

[35] Wanous JP, Reichers AE, Hudy MJ. Overal Job Satisfaction: How Good are Single-Item Measures? Journal of Applied Psychology. 1997; 82(2): 247-252. PMid: 9109282. http://dx.doi.org/10. 1037/0021-9010.82.2.247

[36] Brien M, Forest J, Mageau GA, et al. The Basic Psychological Needs at Work Scale: Measurement Invariance between Canada and France. Applied Psychology: Health and Well-Being. 2012; 4(2): 167-187. http://dx.doi.org/10.1111/j.1758-0854.2012.01067.x

[37] Geller G, Bernhardt BA, Carrese J, et al. What Do Clinicians Derive from Partnering with their Patients? A Reliable and Valid Measure of "Personal Meaning in Patient Care". Patient Education and Counseling. 2008; 72(2): 293-300. PMid: 18485656. http://dx.doi.org/10.1016/j.pec.2008.03.025

[38] Smith BW, Dalen J, Wiggins K, et al. The Brief Resilience Scale: Assessing the Ability to Bounce Back. International Journal of Behavioral Medicine. 2008; 15(3): 194-200. PMid: 18696313. http://dx.doi.org/10.1080/10705500802222972

[39] Pearson SD, Goldman L, Orav EJ, et al. Triage Decisions for Emergency Department Patients with Chest Pain: Do Physicians' Risk Attitudes Make the Difference? Journal of General Internal Medicine. 1995; 10(10): 557-564. PMid: 8576772. http://dx.doi.org/10. $1007 / \mathrm{BF} 02640365$

[40] Jakcson DN. Jackson Personality Inventory Manual. Goshen, NY: Research Psychologists Press; 1975.

[41] Gerrity MS, DeVellis RF, Earp JA. Physicians' Reactions to Uncertainty in Patient care. A New Measure and New Insights. Medical Care. 1990; 28(8): 724-736. PMid: 2385142. http://dx.doi.org /10.1097/00005650-199008000-00005

[42] Williams ES, Rondeau KV, Xiao Q, et al. Heavy Physician Workloads: Impact on Physician Attitudes and Outcomes. Health Services Management Research. 2007; 20(4): 261-269. PMid: 17958972. http://dx.doi.org/10.1258/095148407782219067

[43] Shirom A, Nirel N, Vinokur AD. Overload, Autonomy, and Burnout as Predictors of Physicians' Quality of Care. Journal of Occupational Health Psychology. 2006; 11(4): 328-342. PMid: 17059297. http: //dx.doi.org/10.1037/1076-8998.11.4.328

[44] Ilies R, Dimotakis N, De Pater IE. Psychological and Physiological Reactions to High Workloads: Implications for Well-Being. Personnel Psychology. 2010; 63(2): 407-436. http://dx.doi.org/10. $1111 / \mathrm{j} .1744-6570.2010 .01175 . \mathrm{x}$

[45] Mohr DC, Benzer JK, Young GJ. Provider Workload and Quality of Care in Primary Care Settings: Moderating Role of Relational Climate. Medical Care. 2013; 51(1): 108-114. PMid: 23222471. http://dx.doi.org/10.1097/MLR.0b013e318277f1cb

[46] Shirom A, Nirel N, Vinokur AD. Work Hours and Caseload as Predictors of Physician Burnout: The Mediating Effects by Perceived Workload and By Autonomy. Applied Psychology. 2010; 59(4): 539-565. http://dx.doi.org/10.1111/j.1464-0597.2009.00411.x

[47] Willard-Grace R, Hessler D, Rogers E, et al. Team Structure and Culture are Associated With Lower Burnout in Primary Care. Journal of the American Board of Family Medicine. 2014; 27(2): 229-238. 
PMid: 24610185. http://dx.doi.org/10.3122/jabfm. 2014. 02.130215

[48] Helfrich CD, Dolan ED, Simonetti J, et al. Elements of Team-Based Care in a Patient-Centered Medical Home are Associated with Lower Burnout Among VA Primary Care Employees. Journal of General Internal Medicine. 2014; 29 (Suppl 2): S659-S666. PMid: 24715396. http://dx.doi.org/10.1007/s11606-013-2702-z

[49] Alidina S, Rosenthal MB, Schneider EC, et al. Practice Environments and Job Satisfaction in Patient-Centered Medical Homes. Annals of Family Medicine. 2014; 12(4): 331-337. PMid: 25024241 http://dx.doi.org/10.1370/afm. 1662

[50] Ramsbottom-Lucier MT, Caudill TS, Johnson MM, et al. Interactions With Colleagues and Their Effects on the Satisfaction of Rural Primary Care Physicians. Journal of Rural Health. 1995; 11(3): 185-191. PMid: 10151310. http://dx.doi.org/10.1111/j.1748-0361. 1995. tb00414.x

[51] Sullivan MC, Bucholz EM, Yeo H, et al. "Join the Club": Effect of Resident and Attending Social Interactions on Overall Satisfaction Among 4390 General Surgery Residents. Archives of Surgery. 2012 147(5): 408-414. PMid: 22785631. http://dx.doi.org/10.10 01/archsurg. 2012.27

[52] Myers MF. The Well-Being of Physician Relationships. Western Journal of Medicine. 2001; 174(1): 30-33. PMid: 11154663. http: //dx.doi.org/10.1136/ewjm.174.1.30

[53] Hoff T, Whitcomb WF, Nelson JR. Thriving and Surviving in a New Medical Career: The Case of Hospitalist Physicians. Journal of Health and Social Behavior. 2002; 43(1): 72-91. PMid: 11949198. http://dx.doi.org/10.2307/3090246

[54] Hu YY, Fix ML, Hevelone ND, et al. Physicians' Needs in Coping with Emotional Stressors: The Case for Peer Support. Archives of Surgery. 2012; 147(3): 212-217. PMid: 22106247. http://dx.doi . org/10.1001/archsurg. 2011.312

[55] Fernet C, Gagné M, Austin S. When Does Quality of Relationships With Coworkers Predict Burnout Over Time? The Moderating Role of Work Motivation. Journal of Organizational Behavior. 2010; 31(8): 1163-1180. http://dx.doi.org/10.1002/job.673

[56] Masselink LE, Lee SY, Konrad TR. Workplace Relational Factors and Physicians' Intention to Withdraw from Practice. Health Care Management Review. 2008; 33(2): 178-187. PMid: 18360168. http: //dx.doi.org/10.1097/01.HMR.0000304507.50674.28

[57] Karsh B-T, Beasley JW, Brown RL. Employed Family Physician Satisfaction and Commitment to Their Practice, Work Group, and Health Care Organization. Health Services Research. 2010; 45(2): 457-475. PMid: 20070386. http://dx.doi.org/10.1111/j.1 $475-6773.2009 .01077 . x$

[58] Hill RG Jr, Sears LM, Melanson SW. 4000 Clicks: A Productivity Analysis of Electronic Medical Records in a Community Hospital ED. American Journal of Emergency Medicine. 2013; 31(11): 15911594. PMid: 24060331. http://dx.doi.org/10.1016/j.ajem. 2013.06 .028

[59] Block L, Habicht R, Wu A, et al. In the Wake of the 2003 and 2011 Duty Hours Regulations, How Do Internal Medicine Interns Spend Their Time? Journal of General Internal Medicine. 2013; 28(8): 1042-1047. PMid: 23595927. http://dx.doi.org/10.1007/s 11606-013-2376-6
[60] Fairhurst K, May C. What General Practitioners Find Satisfying in Their Work: Implications for Health Care System Reform. Annals of Family Medicine. 2006; 4(6): 500-505. PMid: 17148627 http://dx.doi.org/10.1370/afm. 565

[61] Babbott S, Manwell LB, Brown R, et al. Electronic Medical Records and Physician Stress in Primary Care: Results from the MEMO Study. Journal of the American Medical Informatics Association. 2014; 21(e1): e100-e106. PMid: 24005796. http://dx.doi.org /10.1136/amiajnl-2013-001875

[62] Friedberg MW, Chen PG, Van Busum KR, et al. Factors Affecting Physician Professional Satisfaction and Their Implications for Patient Care, Health Systems, and Health Policy. The Rand Corporation: Santa Monica, CA; 2013.

[63] Gazewood JD, Longo DR, Madsen R. Physician Satisfaction with Medicaid Managed Care: The Missouri Experience. Journal of Family Practice. 2000; 49(1): 20-26. PMid: 10678335.

[64] Spinelli WM. The Phantom Limb of the Triple Aim. Mayo Clinic Proceedings. 2013; 88(12): 1356-1357. PMid: 24290108. http: //dx.doi.org/10.1016/j.mayocp.2013.08.017

[65] McCann CM, Beddoe E, McCormick K, et al. Resilience in the Health Professions: A Review of Recent Literature. International Journal of Wellbeing. 2013; 3(1): 60-81. http://dx . doi .org/10. 5502/ijw.v3i1.4

[66] Coutu DL. How Resilience Works. Harvard Business Review. 2002; 80(5): 46-56. PMid: 12024758.

[67] Taku K. Relationships Among Perceived Psychological Growth, Resilience and Burnout in Physicians. Personality and Individual Differences. 2014; 59(0): 120-123. http://dx.doi.org/10.1016/j.p aid.2013.11.003

[68] Tugade M, Fredrickson B. Regulation of Positive Emotions: Emotion Regulation Strategies that Promote Resilience. Journal of Happiness Studies. 2007; 8(3): 311-333. http://dx.doi.org/10.1007/s 10902-006-9015-4

[69] Cooke G, Doust J, Steele M. A Survey of Resilience, Burnout, and Tolerance of Uncertainty in Australian General Practice Registrars. BMC Medical Education. 2013; 13(2): 1-6. http://dx.doi.org /10.1186/1472-6920-13-2

[70] Sood A, Prasad K, Schroeder D, et al. Stress Management and Resilience Training Among Department of Medicine Faculty: A Pilot Randomized Clinical Trial. Journal of General Internal Medicine. 2011; 26(8): 858-861. PMid: 21279454. http://dx.doi .org/10. $1007 / \mathrm{s} 11606-011-1640-\mathrm{x}$

[71] Epstein RM, Krasner MS. Physician Resilience: What It Means, Why It Matters, and How to Promote It. Academic Medicine. 2013; 88(3): 301-303. PMid: 23442430. http://dx.doi.org/10.1097/ACM $.0 \mathrm{~b} 013 \mathrm{e} 318280 \mathrm{cff} 0$

[72] Mallak LA. Measuring Resilience in Health Care Provider Organizations. Health Manpower Management.1998; 24(4-5): 148-152. PMid: 10346317. http://dx.doi.org/10.1108/09552069810 215755

[73] Peckham C. Physician Lifestyle Report 2015. Medscape, LLC, New York, NY

[74] Keeton K, Fenner DE, Johnson TRB, et al. Predictors of Physician Career Satisfaction, Work-Life Balance, and Burnout. Obstetrics and Gynecology. 2007; 109(4): 949-955. PMid: 17400859. http: //dx.doi.org/10.1097/01.AOG.0000258299.45979.37 